\title{
MODEL OF HUMAN RESOURCES \\ PERFORMANCE IMPROVEMENT AT PORT \\ OPERATOR UNIT (UPP) CLASS III JEPARA, \\ PATI AND REMBANG THROUGH KNOWLEDGE \\ SHARING, QUALITY OF INFORMATION \\ TECHNOLOGY AND COMMITMENT \\ AS INTERVENING VARIABLE
}

\author{
Sugito $^{1^{*}}$, Nunung Ghoniyah ${ }^{2 *}$
}

* Affiliation:

${ }^{1,2}$ Officer at Port Operator Unit (UPP) Class III Jepara

\begin{abstract}
:
This study aimed to examine the effect of knowledge sharing and quality of information technology on performance. In addition, this study used commitment as intervening variable to test the correlation between knowledge sharing and quality of information technology on performance. This research was conducted with survey method by distributing questionnaires to 100 employees of the Port Operator Unit (UPP) Class III Jepara, Pati and Rembang. The Sampling was done by using simple random sampling technique for the Port Operator Unit (UPP) Class III Jepara, Pati and Rembang. Furthermore, the commitment as an intervening variable is able to mediate the correlation on the effect of knowledge sharing and quality of information technology on performance.
\end{abstract}

Keywords: Knowledge Sharing, Quality Information Technology, Commitment, Performance

\section{INTRODUCTION}

Employees Performance in an organization is one source for benchmarks assessment of the quality of an organization. Therefore, it can be said that if an organization has a satisfying performance, then the organizational performance cannot be underestimated. Port Operator Unit (UPP) class III Jepara, Pati and Rembang is one of the agencies that has a major role in supporting the smoothness of the economy, especially for domestic and international trading activities, visit the ship, loading and unloading of goods and the ups and downs of passengers. Therefore, the role of professional employee is required in order to improve quality service to satisfy community. 
There are many cases At Port operator unit (UPP) class III Jepara, Pati and Rembang which allegedly resulted in the low performance of employees and it can be seen from the low level of attendance of employees and employees who are out of the office due to personal or family affairs. That is because there are employees who are given heavy workloads and under pressure from his boss so that employees feel less comfortable in the work environment. As a result, they are stressful which impact negatively on performance. Conversely, there are also employees who work casually, have a light workload and tolerated if the work is not good. This is because the manager is less assertive, which causes the employee seem slow in completion of duties. If this condition is not immediately addressed, even though the employee is working maximally, in the future it is feared that it will affect employee performance.

One of the efforts to improve quality service and employee performance in the harbor can be achieved through the implementation of knowledge sharing among employees. As obtained in the research of Widodo (2013) and Wahyuni and Kistyanto (2013), it was asserted that if knowledge sharing is higher, then the performance of employees will be higher. However, Sen $\mathrm{Wu}$, et. al (2012) in his research showed that the measu $\mathrm{r}$ ement of knowledge sharing in interpersonal relationships has significant effect on e m ployee performance. Kosasih and Budiani (2007) stated that knowledge sharing directly has no significant effect on employee performance.

The implementation of knowledge sharing is done at the employees section of administrative staff, relevant information concerning the application of knowledge sharing can be obtained from a combination of operational coordinator and implementations since they represent contributions and responsibilities of each other on the success of knowledge sharing. However, the implementation of knowledge sharing in the Port operator unit (UPP) class III Jepara, Pati and Rembang still felt less strong, it is shown by the form of knowledge sharing itself. The form of knowledge sharing in the Port Office in Jepara, Pati and Rembang is in formal form such as seminars, workshops, sharing info, sharing rules, and training that are incorporated in a national meeting involving all leaders and employees. In addition, the informal form of knowledge sharing is the explanation of instructions from superiors to subordinates, division briefings, knowledge sharing done via email and also mailing list.

HR performance improvement is also inseparable from the quality of information technology. The rapid development of technology requires organization to develop system and information technology. Research results by Antasari and Yaniartha (2015), Astuti and Dharmadiaksa (2014), Alraja and Alomiam (2013) found that the utilization of information system positively affects performance. Conversely, The research results by Retriana (2013) and Lindawati and Salamah (2012) explained that the use of information systems does not give a significant effect on performance.

The phenomenon in every agency at present is faced with technological developments. Since the development of such technologies, agencies must always keep up with it quickly in order not to be left behind with the competitors. For that reason, it is needed to have human resources who have skill and knowledge about information technology. In Port Operator Unit (UPP) class III Jepara, Pati and Rembang, associated with information technology, it is 
hampered by the existence of human resources who have exceeded 50 years who have no basic skills and knowledge about information technology though the Port operator Unit (UPP) class III Jepara, Pati and Rembang is demanded to provide fast service. Therefore, we need to pay attention in this matter. The purpose of this research is to analyze the effect of Knowledge Sharing and the quality of information technology on the human resources performance at the Port Operator Unit (UPP) Class III Jepara, Pati and Rembang through commitment as intervening variable.

\section{LITERATURE REVIEW HR performance}

The term performance comes from the word Job performance or performance which means the achievement of work or achievement actually achieved by employees (Mangkunegara, 2008: 67). Usually high-performance employees are called productive employees and conversely employees whose level of performance does not achieve standards are said to be unproductive or low performing employees. In Another word, performance is the work achieved by employees in carrying out the tasks assigned to him in accordance with the criteria set. Employee performance is closely related to the work of someone in an organization. The results of the work can involve quality, quantity, and timeliness.

Employees Performance in the organization is of course different, depending on the factors that influence it. The sense of satisfaction that employees get when they work can make them work optimally and show the best results. It is a manifestation of reciprocity that employees give to the organization. In addition to providing satisfaction to employees, the excitement of work by providing motivation needs to be created so that employees work effectively.

\section{Knowledge Sharing}

Bock, et.al., in Chalifa and Nugrohoseno (2014: 726), defined knowledge sharing as a process in which individuals exchange their knowledge (tacit knowledge and explicit knowledge). This definition implies that every knowledge sharing behavior consists of bringing (knowledge donating) and getting (knowledge collecting). Knowledge donating is the behavior of communicating one's intellectual capital to another. While knowledge collecting is an individual's behavior to consult with another individual about his or her own intellectual capital. Both of these behaviors have different properties and can have different effects.

Knowledge sharing is an activity of transferring and disseminating knowledge from one person, group or organization to the others. This definition includes tacit and explicit knowledge. Knowledge sharing can be formed in many forms such as: a story that describes a similar experience in which methods or techniques are developed or used to solve problems. If it cannot provide a direct solution, knowledge can be shared in relation to contacting someone who may know and be willing and able to help.

\section{Quality of Information Technology}

The quality of information technology is a set of components that work together to achieve goals or targets (Baridwan, 2003: 3). Systems within the scope of information are 
defined as a set of components that work together to achieve goals or targets (Baridwan, 2003: 
3). It is also described as Interconnected components for collecting, processing and storing information for the purpose of assisting planning, controlling, coordinating and organizational decision making.

The information system is a framework in which resources (human and computer) are coordinatedtoconvertinputs(data)intooutputs(information)toachieve organizational goals. The main system functions are receiving, processing, and producing outputs. The function is to run properly, the system will have the components of input, process, output and control to ensure that all functions work properly. Information is data that has been processed so it can be used for decision-making. Data is a representation of an object. For example: the student is represented by the Student Identity Number (NIP), then such number is the data. The unprocessed data cannot be used for decision making.

\section{COMMITMENT}

Commitments is the most essential thing in the elements of formulating performance, because performance will be generated from the commitment of employees to work in the organization. Organizational commitment becomes the most important element in shaping performance. There are many management experts explain about organizational commitment. Sopiah (2008: 157) defined organizational commitment as an employee's psychological bond to an organization which is characterized by strong trust and acceptance of the organization's goals and values, a willingness to try to achieve organizational interests and a strong desire to maintain a position as a member of the organization.

According to Mowday, in Sopiah (2008: 155), organizational commitment is an important behavioral dimension that can be used to assess employee inclination. Organizational commitment is a relatively strong identification and involvement of a person to the organization. Organizational commitment is the desire of members of the organization to keep maintaining membership in the organization and are willing to strive for the achievement of organizational goals. Based on the above understanding, it can be stated that organizational commitment is defined as the attitude of employees to organize by receiving and upholding the good name of the organization and practice the culture contained within the organization.

\section{CONCEPTUAL FRAMEWORK}

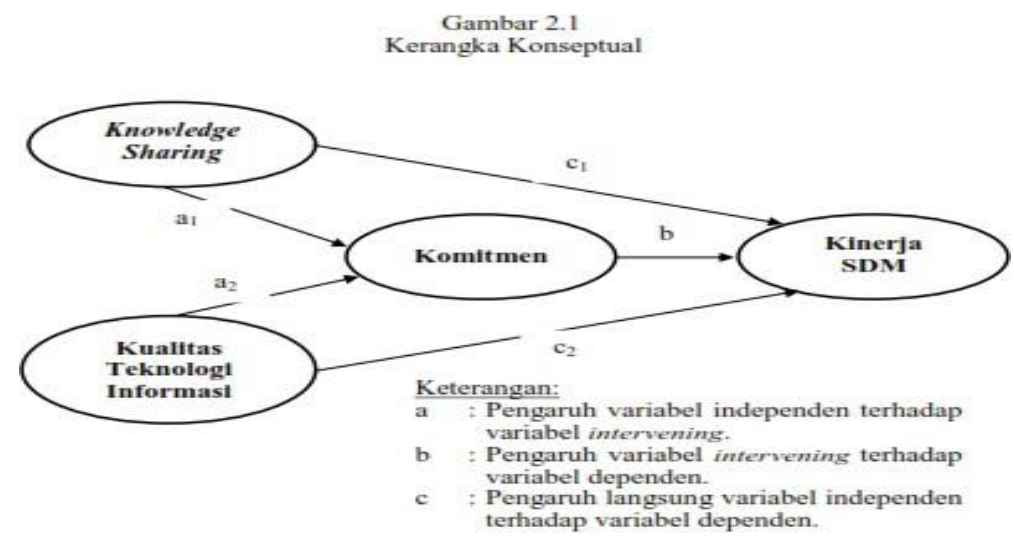




\section{RESEARCH METHODS}

This is explanative research by using a quantitative approach. This research was conducted at port operator unit (UPP) class III Jepara, Pati and Rembang. The population in this study were employees of port operator unit (UPP) class III Jepara, Pati and Rembang which amounted to 116 employees with a sample of 100 by using simple random sampling technique. Data analysis technique was done by PLS method (Partial Least Square). This method was used to know the effect of knowledge sharing, quality of information technology, and commitment on the performance of officer of port operator unit (UPP) class III Jepara, Pati and Rembang. To test indirect effect through the intervening variable was done by using Sobel test.

\section{RESULTS AND DISCUSSION Research Findings}

Inner model or structural model testing is done to see the correlation between construct, significance value and R-square of the research model. The structural model was evaluated by using R-square for the t-test dependent construct as well as the significance of the structural path parameter coefficients. Results of data processing are shown in the following figure:

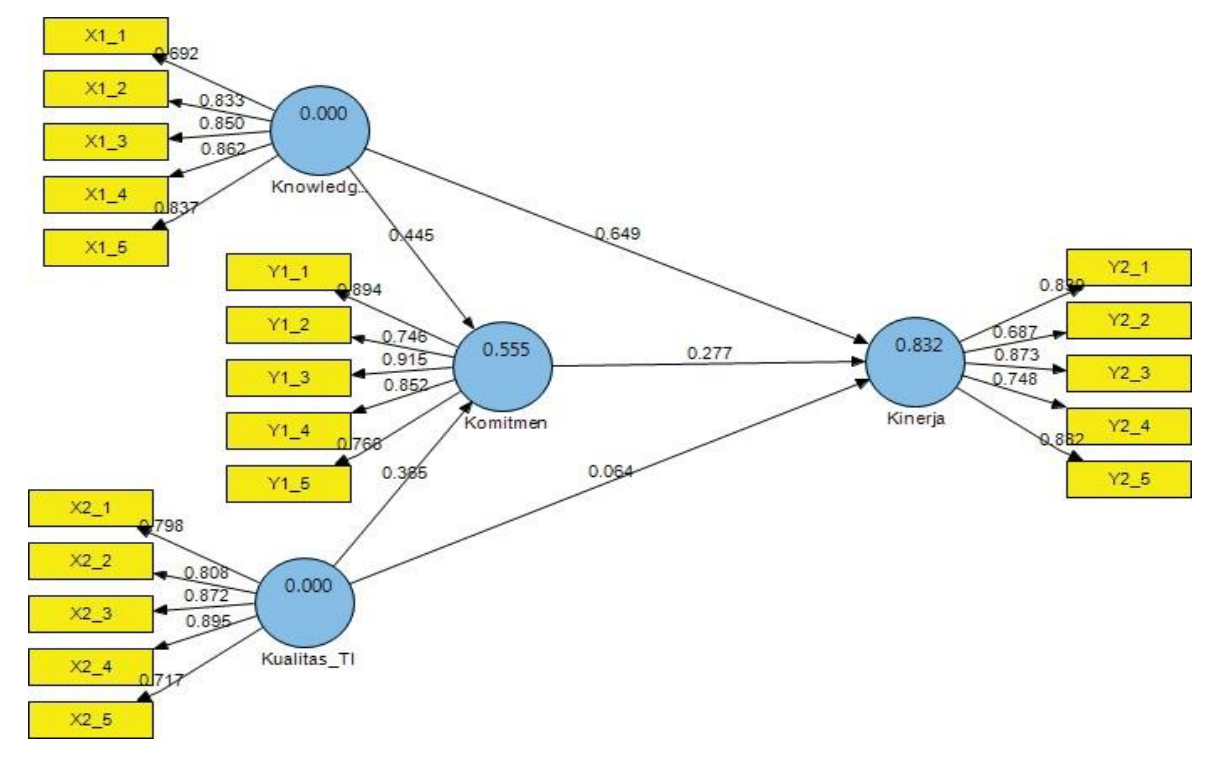

To assess the model with PLS, it was started by looking at R-square for each dependent latent variable.

\begin{tabular}{|l|l|l|}
\hline No. & Variables & R-square \\
\hline 1. & Commitment & 0.554664 \\
\hline 2. & Performance & 0.832358 \\
\hline
\end{tabular}

The table above shows the value of R-square for Commitment variables is 0.554664 and for performance variables is 0.832358 . These results indicate that $55.5 \%$ of Commitment variables are affected by Knowledge Sharing and Quality of Information Technology and $83.23 \%$ of Performance variables are influenced by Knowledge Sharing, Quality of Information Technology and Commitment. 


\section{Direct Effect Hypothesis Testing}

The significance of estimated parameters provides very useful information on the correlation between research variables. The basis used in testing the hypothesis is the value contained in the output result for inner weight.

\begin{tabular}{|l|l|l|l|l|}
\hline \multicolumn{1}{|c|}{ Construct } & Original Sample & Sample Mean & $\begin{array}{c}\text { Standard } \\
\text { Error }\end{array}$ & \multicolumn{1}{|c|}{ T Statistics } \\
\hline Knowledge_Sharing -> Commitment & 0.445437 & 0.457433 & 0.114468 & 3.891350 \\
\hline Quality_IT -> Commitment & 0.365191 & 0.363511 & 0.105344 & 3.466663 \\
\hline Knowledge_Sharing -> Performance & 0.772342 & 0.775103 & 0.049495 & 15.604433 \\
\hline Quality_IT -> Performance & 0.164887 & 0.162683 & 0.050890 & 3.240053 \\
\hline Commitment -> Performance & 0.276986 & 0.284585 & 0.092923 & 2.980809 \\
\hline
\end{tabular}

\section{Indirect Effect Hypothesis Testing}

To Test the effect of independent variables to dependent variable indirectly is done through intervening variable. In this study, it was by using Sobel Test formula with the assistance of application Sobel test Calculator : The test results of indirect effect through commitment as intervening variable by using Sobel test Calculator program can be presented in the following table:

\begin{tabular}{|l|l|l|}
\hline Construct & T Statistics & P Value \\
Knowledge_Sharing -> Commitment -> Performance & 2.36635 & 0.01796 \\
\hline Quality_IT -> Commitment -> Performance & 2.260797 & 0.02725 \\
\hline
\end{tabular}

\section{DISCUSSION}

1. The effect of knowledge sharing on human resource commitments at Port Operator Unit (UPP) Class III Jepara, Pati and Rembang

Theresultsofthefirsthypothesistestingshowedthatthe knowledgesharing variable affects the commitment of human resources in the Port Operator Unit (UPP) Class III Jepara, Pati and Rembang with the path coefficient value of 0.445437 with the $t_{\text {statistic }}$ value of 3.891350. Based on the result of hypothesis test, it can be concluded that knowledge sharing has a significant positive effect on human resource commitment in Port Operator Unit (UPP) of Class III Jepara, Pati and Rembang. This result indicates that knowledge sharing which is done well in Port operator unit (UPP) Class III Jepara, Pati and Rembang tends to increase employee commitment at Port operator unit (UPP) Class III Jepara, Pati and Rembang. The results of this study support the research by Sumarlin, et al (2013) which concluded that the commitment can be directly affected by knowledge sharing. The high willingness of the employees of Port operator unit (UPP) Class III Jepara, Pati and Rembang to share new knowledge to colleagues is able to increase employee commitment because it can be known from the new knowledge sharing indicators on knowledge sharing variables which get the highest average value compared to other indicators. In addition, the indicators of sharing new information about the work is one 
of the factors in supporting the increase in the commitment of employees of Port Operator Unit (UPP) Class III Jepara, Pati and Rembang.

\section{The effect of quality of information technology on human resource commitment at Port Operator Unit (UPP) Class III Jepara, Pati and Rembang}

The result of the second hypothesis test shows that the variable of the quality of information technology significantly affects employee commitment at the Port Operator Unit (UPP) Class III Jepara, Pati and Rembang with the path coefficient value of 0.365191 with $t_{\text {statistic }}$ value of 3.466663. Based on the result of hypothesis test, it can be concluded that the quality of information technology has a significant positive effect on human resource commitment on Port Operator Unit (UPP) Class III Jepara, Pati and Rembang. These results indicate that employee at Port Operator Unit (UPP) Class III Jepara, Pati and Rembang will have a good commitment to the organization if supported by the good quality of information technology. This result is in accordance with research by Ratifah and Ridwan (2012) which explains that the quality of information technology has significant effect on employee commitment.

The security factor becomes one of the highest indicators on the quality of information technology variables. The security in using the information technology provided makes the employees of the Port Operator Unit (UPP) of Class III Jepara, Pati and Rembang feel safe and do not need to be anxious in carrying out their work, because the confidentiality of their work is safe. In addition, the speed factor of accessing information technology is also able to cause the employees of Port Operator Unit (UPP) Class III Jepara, Pati and Rembang feel satisfied with the quality of information technology. Employee Satisfaction makes HR commitment at Port Operator Unit (UPP) Class III Jepara, Pati and Rembang to the organization become good. So that the quality of information technology significantly affects the commitment of human resources at Port operator unit class III of Jepara, PAti and Rembang.

Utilization of information technology can be done effectively if employees can use the technology well. At Port operator Unit (UPP) class III Jepara, Pati and Rembang associated with information technology, it is hampered by the existence of human resources who have exceeded 50 years and lack of basic skills and knowledge about information technology. One of the methods to improve information processing is by increasing employee involvement. Employees with high involvement in the organization will be able to increase their organizational commitment.

\section{The effect of knowledge sharing on the performance of human resources at Port Operator Unit (UPP) Class III Jepara, Pati and Rembang}

The result of the third hypothesis test showed that the knowledge sharing variable significantly affects HR performance at Port Operator Unit (UPP) of Class III Jepara, Pati and Rembang with the coefficient value of 0.772342 with $t_{\text {statistical }}$ value of 15.604433. Based on the hypothesis test results, it can be concluded that knowledge sharing has a significant positive effect on HR performance at Port Operator Unit (UPP) of Class III Jepara, Pati and Rembang. This result shows that knowledge sharing of one employee to others give the overall renewal of knowledge in the Port Operator Unit (UPP) Class III Jepara, 
Pati and Rembang, which in turn will provide the unique organizational characteristics to the organization and further its competitors can improve performance. The results of this study of support research by Widodo (2013) and Wahyuni and Kistyanto (2013) which asserted that the higher the knowledge sharing, the higher the employee performance.

Sharing new knowledge either related to work or new science conducted by staff of Port Operator Unit (UPP) class III Jepara, Pati and Rembang to colleagues is able to improve employee performance. With the addition of new knowledge and experiences gained, the employee will be more competent and professional. It can be seen from the indicators of quality of work in performance variables that showed a higher average value if compared to other indicators.

Knowledge sharing is an effective approach to achieve the competitive advantage derived from organizational maintenance. Knowledge sharing of an individual on information systems will be able to provide updates to the overall knowledge of the organization, which in turn will provide the organizational characteristics and improve performance. A well-run Knowledge sharing at the Port Operator Unit (UPP) Class III Jepara, Pati and Rembang between administrative staff and executive employees is able to increase employee performance. The synergy between the individual and organizational knowledge in managing good management is very important to produce a potential resource in making the right and profitable strategy for the Port Operator Unit (UPP) Class III Jepara, Pati and Rembang.

\section{The Effect of The quality of information technology quality on HR performance at Port Operator Unit (UPP) Class III Jepara, Pati and Rembang}

The fourth hypothesis testing results indicated that the variable of quality of information technology has a significant effect on HR performance in the Port Operator Unit (UPP) Class III Jepara, Pati and Rembang with the path coefficient value of 0.164887 and $\mathrm{t}_{\text {statistic }}$ of 3.240053. Based on the hypothesis test results, it can be concluded that the quality of information technology has a significant positive effect on HR performance at Port Operator Unit (UPP) Class III Jepara, Pati and Rembang. These results indicate that the officers of the Port Operator Unit (UPP) Class III Jepara use information technology because of knowing the benefits of the utilization of information technology that will improve performance. The results of this study support the research of Antasari and Yaniartha (2015), Astuti and Dharmadiaksa (2014), Alraja and Alomiam (2013) who found that the use of information technology positively affects performance.

The quality of information technology will make it easier for employees to absorb existing information and communicate quickly and accurately. Good communication will lead to mutual understanding and comfort in work. Such a thing can minimize the occurrence of miss-understanding in two-way communication between superiors and subordinates within the organization. The role of information technology in the Port Operator Unit (UPP) Class III Jepara, Pati and Rembang is very important, so every employee in everyday tasks use information technology vertically (superior-subordinate) and horizontally (colleague). Employee at Port Operator Unit (UPP) Class III Jepara, Pati and Rembang feel comfortable with the quality of existing information technology so that it is regarded by employees as one of the important factors that drive the improvement of productivity and performance. 


\section{The effect of human resource commitment on HR performance at Port Operator Unit (UPP) Class III Jepara, Pati and Rembang}

The result of the fifth hypothesis test shows that the commitment variable significantly affects HR performance at the Port Operator Unit (UPP) Class III Jepara, Pati and Rembang with the path coefficient value of 0.276986 with a $t_{\text {statistic }}$ value of 2.980809 . Based on the result of hypothesis test, it can be concluded that HR commitment has a significant positive effect on HR performance at Port Operator Unit (UPP) Class III Jepara, Pati and Rembang. These results indicate that employees at Port Operator Unit (UPP) Class III Jepara, Pati and Rembang will have a good performance if accompanied by the improvement of commitment to the organization. The result of this study is in line with the study by Desmiyawati \& Witaliza study (2013) which concluded that the commitments affects employee performance.

Officers of Port Operator Unit (UPP) of Class III Jepara, Pati and Rembang, when viewed from indicator of commitment, mostly have good commitment although there are still some employees who have continuous commitment which still less good because there is still hesitant answer of employee for that indicator. This illustrates that there is still an employee at Port Operator Unit (UPP) Class III Jepara, Pati and Rembang who still think for leaving organizations and look for the better one, and are not concerned on personal sacrifice already incurred to advance the organization.

Meanwhile, on affective and normative commitment, the officers of Port operator Unit (UPP) Class III Jepara, Pati and Rembang show feelings of pride and feel to be part of the organization, so that employees show their loyalty by working in full responsibility and thoroughness. By creating strong feelings and attachments within the organization, increasing loyalty is a way of keeping employees committed. The growing sense of commitment of each employee to the organization will bring employees to the will and the decision to remain in the organization and help promote the organization through improved performance and achieve the vision and mission.

\section{The indirect effeet of knowledge sharing on HR performance at the Port Operator Unit (UPP) Class III Jepara, Pati and Rembang through commitment as intervening variable}

The result of the sixth hypothesis test shows that the knowledge sharing variable significantly affects HR performance at Port Operator Unit (UPP) of Class III Jepara, Pati and Rembang through commitment as intervening variable with the t- ${ }_{\text {statistic }}$ value of 2.36635. The effect of Knowledge sharing on HR performance at the Port Operator Unit (UPP) Class III Jepara, Pati and Rembang with commitment as an intervening variable show significant positive correlation. Hypothesis testing is done by using Sobel Test. This means that the mediation parameters are significant. Then the indirect effect model of knowledge sharing variable on HR performance at Port Operator Unit (UPP) Class III Jepara, Pati and Rembang through commitment as intervening variable can be accepted.

The process of knowledge sharing is related to how the human resources within the organization share work-related experience, expertise, know - how and information with other colleagues. The process of sharing knowledge can be understood as a process through 
which the human resources knowledge exchange and equally create new knowledge. The Success in the implementation of knowledge sharing depends on the employee's attitude towards knowledge sharing. Attitudes toward knowledge sharing is influenced by the intention of employees to do knowledge sharing.

\section{The indirect effect of the quality of information technology on HR performance at the Port Operator Unit (UPP) Class III Jepara, Pati and Rembang through commitment as intervening variable}

The result of testing of the seventh hypothesis shows that the variable of information technology quality has significant effect on HR performance through the commitment as intervening variable with the $\mathrm{t}$ statistic value of 2.260797. The effect of the quality of information technology on HR performance at the Port Operator Unit (UPP) Class III Jepara, Pati and Rembang with commitment as intervening variable shows a significant positive correlation. Testing of this seventh hypothesis is done by using Sobel Test calculation. This means that the mediation parameters are significant. Then the model of indirect effect of the variable of quality of information technology on HR performance at port operator Unit (UPP) Class III Jepara, Pati and Rembang through commitment as intervening variable can be accepted. The results of this study are in accordance with research by Ratifah and Ridwan (2012) which concluded that the commitment is able to moderate the effect of the accounting system on quality or performance.

The existence of a strong commitment is needed for the organization in order to improve performance accountability as well as good use of the resulting performance information. Thus, commitment has a positive effect on employee performance on the organization. One of the factors that can affect performance accountability is the quality of information technology, because the development of information system can increase employees' commitment because it can increase employee capability and enable various activities to be carried out quickly, precisely and accurately, thus ultimately, it will improve performance.

\section{CONCLUSIONS AND RECOMMENDATIONS}

The results showed that knowledge sharing, quality of information technology and commitment directly affect employee performance at Port operator Unit (UPP) Class III Jepara, Pati and Rembang. In addition, commitment as an intervening variable can be a mediating variable of knowledge sharing and quality of information technology which directly affects performance.

The recommendation proposed in this research is employee performance will be able to run well if supported by high commitment from organization. Although commitment of officer of Port Operator Unit (UPP) Class III Jepara, Pati and Rembang have been able to improve performance, the leadership need to continue to foster employee commitment in order to maintain employee performance to remain high, and must continue to develop a system of knowledge sharing on an ongoing basis until employees can work better. 


\section{REFERENCE}

Alraja, Mansour Naser \& Nayef Rage Alomiam. 2013. The Effect Of Information Technology In Empowerment Public Sector Employees: A Field Study. Interdisciplinary Journal of Contemporary Research In Business Vol 5, No 1, May 2013. p. 805-815.

Antasari, Kadek Chendi dan Pt D'yan Yaniartha. 2015. Pengaruh Efektivitas Sistem Informasi Akuntansi dan Penggunaan Teknologi Informasi pada Kinerja Individual dengan Kepuasan Kerja Sebagai Variabel Pemoderasi. E-Jurnal Akuntansi Universitas Udayana, Vol. 10, No. 2. Februari 2015, h. 354-369.

Astuti, Ni Made Marlita Puji dan Ida Bagus Dharmadiaksa. 2014. Pengaruh Efektivitas Penerapan Sia, Pemanfaatan, dan Kesesuaian Tugas pada Kinerja Karyawan. E-Jurnal Akuntansi Universitas Udayana, Vol. 7, No. 3. Desember 2014, h. 747-753.

Baridwan, Zaki. 2003. Sistem Akuntansi Penyusunan Prosedur dan Metode. Edisi Kelima. Yogyakarta: BPFE.

Chalifa, Noer dan Dwiarko Nugrohoseno. 2014. Pengaruh Berbagi Pengetahuan terhadap Kinerja Karyawan Melalui Kerja Tim. Jurnal Ilmu Manajemen, Vol. 2, No. 3, Juli 2014 : $724-734$.

Desmiyawati \& Wulan Witaliza. 2013. Pengaruh Komitmen Organisasi, Pengendalian Intern dan Akuntabilitas Publik terhadap Kinerja Organisasi (Studi Empiris pada Rumah Sakit Swasta di Provinsi Riau). Pekbis Jurnal, Vol.4, No.1, Maret 2012: 26-33.

Kosasih, Natalia dan Sri Budiani. 2007. Pengaruh Knowledge Management terhadap Kinerja Karyawan: Studi Kasus Departemen Front Office Surabaya Plaza Hotel. Jurnal Manajemen Perhotelan, Vol. 3 No.2, September 2007: 80 - 88.

Lindawati dan Irma Salamah. 2012. Pemanfaatan Sistem Informasi dan Teknologi Informasi Pengaruhnya terhadap Kinerja Individual Karyawan. Jurnal Akuntansi dan Keuangan, Vol. 14, No. 1, Mei 2012. h. 56-68.

Mangkunegara, Anwar P. 2008. Manajemen Sumber Daya Manusia Perusahaan. Bandung: PT. Remaja Rosdakarya.

Ratifah, Ifa dan Mochammad Ridwan. 2012. Komitmen Organisasi Memoderasi Pengaruh Sistem Akuntansi Keuangan Daerah terhadap Kualitas Laporan Keuangan. Trikonomika, Vol. 11, No. 1, Juni 2012: 9 - 39.

Retriana, Bela. 2013. Pengaruh Pemanfaatan Teknologi Informasi terhadap Kinerja Individual pada Kantor Dinas Kependudukan dan Pencatatan Sipil Kabupaten Wonogiri. Jurnal Penelitian Ekonomi dan Bisnis Universitas Muhammadiyah Surakarta, Juni 2013. $h$. 1-17. 
Sen Wu, Chao., Cheng- Jong Lee, Li - Fen Tsai. 2012. Research On The Knowledge Sharing, Adventure Recreation And Performance Of Information System R\&D Personnel. The International Journal of Organizational Innovation, Online, 5 (1): 1493-1513.

Sopiah. 2008. Perilaku Organisasi. Yogyakarta: Andi.

Sumarlin, Antonius Widyatma, Agus W Soehadi, Budi Suharjo \& Heny K Daryanto. 2013. Pengaruh Wadah Berbagi Pengetahuan terhadap Komitmen dari Komunitas Merk. Jurnal Manajemen Teknologi, Vol. 12, No. 1: 88 - 101.

Wahyuni, Rista Ramadhan Tri dan Anang Kistyanto. 2013. Pengaruh Berbagi Pengetahuan terhadap Kinerja Departemen melalui Inovasi Jasa/ Pelayanan. Jurnal Ilmu Manajemen, Volume 1 Nomor 4 Juli 2013: 1076 - 1088.

Widodo. 2013. Peran Knowledge Sharing terhadap Kinerja UKM Berbasis Sikap Kewirausahaan. EKOBIS, Vol. 14, No. 2, Januari 2013: 17-27. 